\title{
PERBANDINGAN PENGUKURAN KONSENTRASI PARTIKULAT DI UDARA AMBIEN MENGGUNAKAN ALAT HIGH VOLUME AIR SAMPLER DAN GENT STACKED FILTER UNIT SAMPLER
}

\section{MEASUREMENT COMPARISON OF PARTICULATE CONCENTRATION IN AMBIEN AIR USING HVAS AND GENT STACKED FILTER UNIT SAMPLER}

\author{
Rita Mukhtar ${ }^{1)}$, Isa Ansyori1), Esrom Hamonangan'1), Muhayatun Santoso(2), Diah Dwiana Lestiani²) \\ (Diterima tanggal 12-10-2014; Disetujui tanggal 09-12-2014)
}

\begin{abstract}
ABSTRAK
Pengambilan contoh uji partikulat di udara ambien dapat dilakukan dengan menggunakan peralatan yang berbeda yaitu High Volume Air Sampler (HVAS) dan Gent Stacked Filter Unit Sampler. Untuk mengetahui hasil dari kedua metode sampling tersebut, Pusarpedal melakukan pengambilan contoh uji menggunakan kedua alat tersebut dan mengukur parameter logam berat timbal $(\mathrm{Pb})$ sesuai yang tercantum di dalam Lampiran Peraturan Pemerintah No. 41 Tahun 1999 tentang Pengendalian Pencemaran Udara. Penelitian ini bertujuan untuk mendapatkan rasio atau perbandingan konsentrasi $\mathrm{Pb}$ yang didapat dari alat HVAS dan Gent stacked filter unit sampler. Contoh uji Total Suspended Particulate (TSP) yang didapat dari alat HVAS merupakan partikel yang berada pada ukuran 0-100 $\mu \mathrm{m}$, dan analisis kandungan logam timbal $(\mathrm{Pb})$ dalam sampel ini dilakukan menggunakan Atomic Absorption Spectrometry (AAS). Sedangkan pada alat Gent Stacked Filter Unit Sampler ukuran partikel yang diperoleh adalah

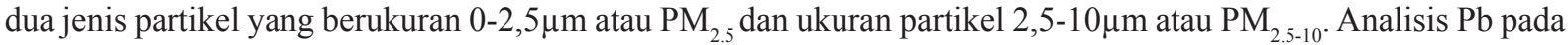
sampel ini dilakukan menggunakan Particle Induced X-ray Emission (PIXE). Hasil pengukuran yang dilakukan pada rentang waktu 25 Agustus sampai 25 September 2008 menunjukkan konsentrasi $\mathrm{Pb}$ pada $\mathrm{PM}_{2,5-10}$ memiliki korelasi yang cukup kuat atau mempunyai pola kecenderungan yang sama terhadap konsentrasi $\mathrm{Pb}$ di TSP dengan nilai $\mathrm{R}^{2}$ sekitar 0,7 .
\end{abstract}

Kata Kunci: logam berat timbal (Pb), Gent Staked Filter Unit sampler, High Volume Air sampler (HVAS), TSP, $\mathrm{PM}_{2.5}, \mathrm{PM}_{2.5-10}$

\begin{abstract}
Particulate matters from ambient air samples have been collected using two techniques with different equipment: High Volume Air Sampler (volume air samplers) and Gent Stacked Filter Unit Sampler at the similar location and period. As a comparison from both sampling techniques, heavy metal concentration, Lead $(\mathrm{Pb})$ has been compared in accordance with the parameters of heavy metals in the appendix to Government Regulation No. 41 of 1999 on Air Pollution Control. Total Suspended Particulate (TSP) which collected using a high volume air sampler were particulates with diameter size 0-100 $\mu$ m, and the lead $(\mathrm{Pb})$ concentration in these samples was analyzed using Atomic Absorption Spectrometry (AAS). Gent Stacked Filter Unit Sampler collected two size fractions of particulates with diameter size 0-2,5 $\mu \mathrm{m}$ or $P M_{2.5}$ and particle size 2,5-10 $\mu \mathrm{m}$ or $P M_{2.5-10^{\circ}}$, the lead concentration in these samples were analyzed using Particles Induced X ray Emission (PIXE). The objective of the study is to obtain the ratio of the results from the measurement using the High Volume Air Samplers and Gent stacked filter units sampler. The results of the measurement during 25th August to 25th September 2008 showed a strong correlation between concentration of $P b$ in $P M_{2,5-10}$ compare to Pb in TSP have with $R^{2}$ values of about 0.7. Hopefully, this data can be used as a reference by other laboratories .
\end{abstract}

Keywords: heavy metals lead (Pb), Gent Staked Filter Unit sampler, High Volume Air sampler (HVAS), TSP, PM 2.5 , $P M_{2.5-10}$

\footnotetext{
${ }^{1}$ PUSARPEDAL - Kementerian Lingkungan Hidup Gd. 210 Kawasan Puspiptek Serpong Tangerang Selatan-Banten 15310, ritaiim@yahoo.com

${ }^{2}$ PSTNT - Pusat Sain Teknologi Nuklir dan Terapan - BATAN Badan Tenaga Nuklir Nasional
} 


\section{PENDAHULUAN}

Pencemaran udara merupakan salah satu penyebab menurunnya kualitas lingkungan dan akan mengakibatkan gangguan kesehatan pada manusia, sedangkan data kualitas udara ambien sangat minim ditemukan. Untuk mengetahui zat pencemar yang terkandung di udara ambien, perlu dilakukan pengambilan contoh uji. Metode dan alat pengambilan contoh uji udara ambien tergantung pada parameter yang akan diuji. Pada lampiran Peraturan Pemerintah Republik Indonesia No. 41 tahun 1999 tentang Pengendalian Pencemaran Udara terdapat beberapa parameter baku mutu udara ambien diantaranya adalah debu atau Total Suspended Particulate (TSP), Particulate matter $\mathrm{PM}_{2.5}$ dan $\mathrm{PM}_{10}$, serta parameter logam berat timah hitam atau timbal $(\mathrm{Pb})$. Peralatan yang digunakan untuk mengambil contoh uji partikel di udara ambien yang tercantum di dalam PP tersebut adalah High Volume Air Sampler (HVAS) dengan metode analisis untuk penentuan partikel adalah gravimetri dan untuk logam $\mathrm{Pb}$ menggunakan Atomic Absorption Spectrometry (AAS) [1].

Sejalan dengan perkembangan ilmu pengetahuan dan teknologi, Pusat Sain dan Teknologi Terapan (PSTNT)-Badan Tenaga Atom Nasional (Batan) memanfaatkan tenaga nuklir dalam analisis contoh uji lingkungan, khususnya udara ambien. Alat yang digunakan untuk mengambil contoh uji udara ambien adalah Gent stacked filter unit sampler, dan analisis menggunakan Teknik Analisis Nuklir (TAN) dalam hal ini menggunakan alat uji Particle Induced E-Ray Emission (PIXE); dimana TAN memiliki beberapa keunggulan dibandingkan cara konvensional diantaranya: TAN dapat langsung menganalisis banyak unsur (multielement), tanpa ada perlakuan (non desktruktif), selective, sensitive, bobot contoh uji kecil serta waktu analisisnya cepat [2].

Penelitian ini bertujuan untuk melihat rasio atau perbandingan hasil yang didapat dari HVAS dan Gent stacked filter unit sampler, sehingga dapat dijadikan sebagai referensi kepada laboratorium yang melakukan pengambilan contoh uji udara ambien.

\section{METODOLOGI}

Pengambilan contoh uji udara ambien menggunakan alat HVAS dan Gent stacked filter unit sampler dilakukan 5 (lima) kali dalam seminggu secara bersamaan pada rentang waktu 25 Agustus sampai 25 September 2008. Lokasi pengambilan contoh uji terdiri dari 4 (empat) lokasi yaitu Perumahan Komplek Batan Indah Serpong, Komplek BSD sektor VIII, sekolahan SDN Setu Muncul Serpong, dan di kantor Pusarpedal-Kementerian Lingkungan Hidup Kawasan Puspiptek Serpong. Pengambilan contoh uji dilakukan pada beberapa variasi waktu untuk masingmasing lokasi.

Parameter yang diuji meliputi kandungan partikel dalam TSP, $\mathrm{PM}_{2.5}, \mathrm{PM}_{2,5-10}, \mathrm{PM}_{10}$, serta logam berat timbal $(\mathrm{Pb})$ yang terkandung didalamnya. Alat HVAS digunakan untuk sampling partikulat berupa Total Suspended Particulate (TSP) dengan ukuran dibawah $100 \mu \mathrm{m}$ sedangkan Gent sampler digunakan untuk sampling partikel dengan ukuran di bawah $10 \mu \mathrm{m}\left(\mathrm{PM}_{10}\right)$ dan di bawah 2,5 $\mu \mathrm{m}$ $\left(\mathrm{PM}_{2.5}\right)$ Hasil sampling dari kedua alat tersebut dianalisa gravimetri untuk mengetahui 
konsentrasi masing-masing parameter TSP, $\mathrm{PM}_{10}, \mathrm{PM}_{2.5}$. Analisa lebih lanjut terhadap kandungan logam $\mathrm{Pb}$ juga dilakukan untuk masing-masing parameter tersebut dengan menggunakan metode Particle Induced $X$-ray Emission (PIXE) di GNS Science, National Isotop Centre, New Zealand. PIXE merupakan teknik analisis yang sangat selektif dengan kepekaan tinggi, simultan dan memiliki batas deteksi mencapai orde submikrogram bahkan nanogram dan hanya memerlukan sampel dalam jumlah kecil. Bila diibandingkan dengan teknik analisis konvensional yang membutuhkan massa yang cukup banyak, perlu preparasi, tidak multielemen, ada interferensi matriks, serta bobot contoh uji yang besar, maka analisis menggunakan teknik nuklir menjadi alternatif baru di bidang analisis parameter udara. Di Amerika Utara hampir 90\% sampel filter dari partikulat di udara diukur menggunakan teknik nuklir. Bahkan Australia dalam 4 tahun terakhir telah menganalisis lebih dari 9000 buah sampel filter menggunakan teknik nuklir, khususnya PIXE. Adapun studi ini hanya mengukur kandungan logam $\mathrm{Pb}$ saja.

\section{Teknik Pengambilan Contoh Uji Menggunakan Alat HVAS}

Teknik pengambilan contoh uji mengacu kepada SNI 19-7119.3-2005 tentang cara uji partikel tersuspensi total menggunakan peralatan $H V A S$ dengan metoda gravimetri. Filter yang digunakan adalah Whatman Glass Microfibre Filters dengan ukuran 20.3 x 25.4 cm (8 x 10 in) EPM 2000.

Prinsip kerja alat $H V A S$ yaitu udara dihisap melalui filter di dalam shelter menggunakan pompa vakum dengan laju alir tinggi sehingga partikel terkumpul di permukaan filter. Jumlah partikel yang terakumulasi dalam filter selama periode waktu tertentu dianalisa secara gravimetri. Laju alir dipantau saat periode pengujian $1200 \mathrm{~L} / \mathrm{min}$, selama 24 jam [3].

Penimbangan dilakukan pada ruangan dengan suhu $15-27^{\circ} \mathrm{C}$, dengan kelembaban relatif antara $0-50 \%$. Konsentrasi partikel tersuspensi total dalam contoh uji dihitung dengan rumus sebagai berikut:

$$
C=\frac{(\mathrm{W} 2-\mathrm{W} 1) \times 10^{6}}{V}
$$

dengan pengertian:

C adalah konsentrasi massa partikel tersuspensi $\left(\mu \mathrm{g} / \mathrm{Nm}^{3}\right)$

$\mathrm{W}_{1}$ adalah berat filter awal $(\mathrm{g})$

$\mathrm{W}_{2} \quad$ adalah berat filter akhir $(\mathrm{g})$

$\mathrm{V}$ adalah volum contoh uji udara $\left(\mathrm{m}^{3}\right)$

$10^{6} \quad$ adalah konversi $\mathrm{g}$ ke $\mu \mathrm{g}$

Hasilnya ditampilkan dalam bentuk satuan massa partikulat yang terkumpul per satuan volum contoh uji udara yang diambil sebagai $\mu \mathrm{g} / \mathrm{m}^{3}$ [3]. Penentuan logam berat menggunakan Atomic Absorbtion Spectrofotometry (AAS)[4].

\section{Teknik Pengambilan Contoh Uji menggunakan Alat Gent Staked Filter Unit} Sampler

Teknik pengambilan sampel partikulat udara mengacu pada Sampling and Analytical Methodologies for Instrumental Nuetron Activation Analysis of Airborne Particulate Matter, Training Course Series No.4, International Atomic Energy Agency, Vienna (1992) serta Operating Manual for Gent Sampler (RAS/7/013), International Atomic Energy Agency (2004) [2]. Filter yang digunakan adalah filter jenis Nuclepore polikarbonat dengan diameter $47 \mathrm{~mm}$ filter 
tersebut terdiri dari dua jenis yaitu ukuran pori $0.4 \mu \mathrm{m}$ yang digunakan untuk penentuan partikel kecil dari 2,5 $\mu \mathrm{m}\left(\mathrm{PM}_{2.5}\right)$, dan filter berukuran pori $8 \mu \mathrm{m}$ yang digunakan untuk penentuan partikel ukuran 2.5-10 $\mu \mathrm{m}$. $\mathrm{PM}_{10}$ adalah partikulat udara yang berukuran lebih kecil dari $10 \mu \mathrm{m}$ yang dapat diperoleh dari penjumlahan $\mathrm{PM}_{2.5}$ dengan $\mathrm{PM}_{2.5-10}[5]$.

Gent sampler terdiri dari sistem pompa vakum dikontrol dengan timer, dan black container (stack filter unit, kaset filter), selang, pompa vakum, volume meter, dan flow meter. Alat Gent direkomendasikan ditempatkan pada ketinggian 6-20 meter di atas tanah. Pompa vakum yang digunakan kuat beroperasi selama 24 jam, karena pengambilan contoh uji dilakukan selama 24 jam. Laju alir udara diatur pada $18 \mathrm{~L} /$ menit [5].

Penimbangan filter/sampel partikulat udara menggunakan neraca mikro Mettler Toledo Tipe AG $245^{2}$ dan tipe MX5. Sebelum dilakukan penimbangan, filter dikondisikan pada suhu ruang dengan temperatur $18-25^{\circ} \mathrm{C}$ dan kelembaban maksimum kurang dari $55 \%$. Penentuan logam berat dilakukan di Laboratorium PSTNT - Batan Bandung [2].

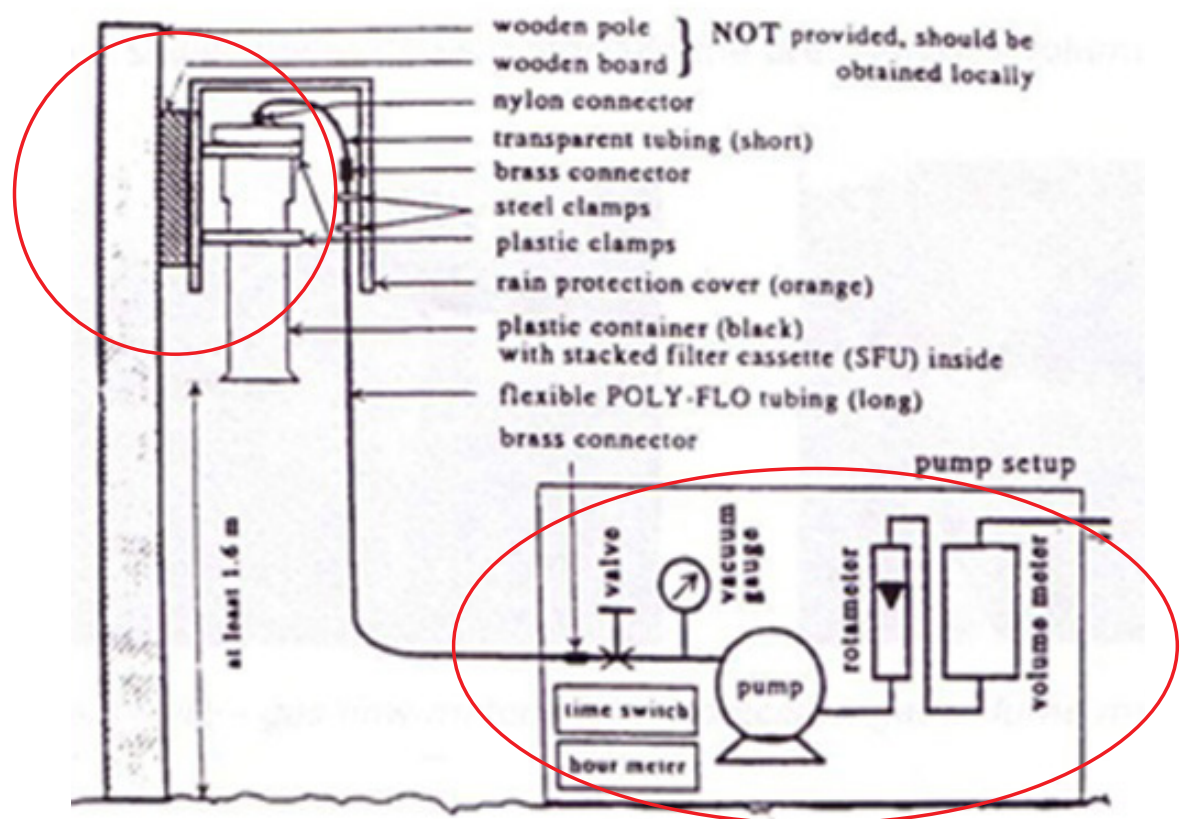

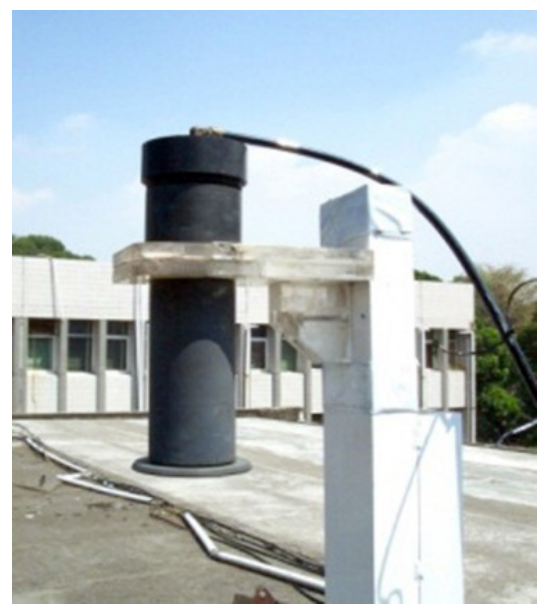

Black Container

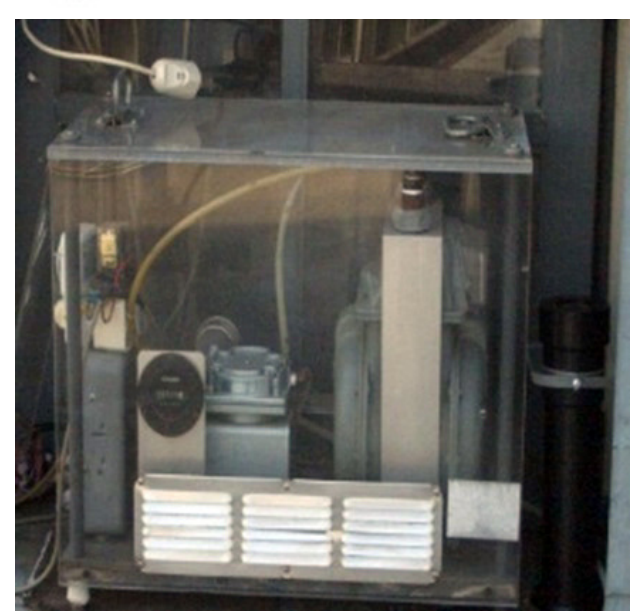

Pompa Vakum

Gambar 1. Skema Bagan Alat Gent Sampler 
$\mathrm{PM}_{2.5}$ dan $\mathrm{PM}_{10}$ diperoleh berdasarkan perhitungan dengan rumus sebagai berikut:

$$
\begin{aligned}
& \mathrm{PM}_{2.5}=\frac{m 1}{v 1}\left(\frac{\mu g}{m 3}\right) \\
& \mathrm{PM}_{2,5-10 \text { (kasar) }}=\frac{m 2}{v 2}\left(\frac{\mu g}{m 3}\right) \\
& \mathrm{PM}_{10}=(\text { PM2.5 }+ \text { PMkasar })
\end{aligned}
$$

dengan keterangan sebagai berikut:

$$
\begin{array}{ll}
\mathrm{m}_{1} & =\text { massa sampler partikulat halus pada filter halus }(\mu \mathrm{g}) \\
\mathrm{v}_{1} & =\text { volume sampler partikulat halus pada filter halus }\left(\mathrm{m}^{3}\right) \\
\mathrm{m}_{2} & =\text { massa sampler partikulat kasar pada filter } \operatorname{kasar}(\mu \mathrm{g}) \\
\mathrm{v}_{2} & =\text { volume sampler partikulat kasar pada filter } \operatorname{kasar}\left(\mathrm{m}^{3}\right)
\end{array}
$$

\section{HASIL DAN PEMBAHASAN}

\section{Perbandingan Konsentrasi Partikulat Di Udara Ambien Menggunakan HVAS Dan Gent Stacked Filter Unit Sampler}

Hasil analisis TSP di semua lokasi yang dipantau pada periode pengukuran 25 Agustus sampai 25 September 2008 berada dibawah baku mutu udara ambien menurut PP 41/1999 yaitu $230 \mu \mathrm{g} / \mathrm{Nm}^{3}$. Kisaran nilai TSP di Setu $116-224 \mu \mathrm{g} / \mathrm{Nm}^{3}$, Batan Indah 74-176 $\mu \mathrm{g} /$ $\mathrm{Nm}^{3}$, BSD $82-215 \mu \mathrm{g} / \mathrm{Nm}^{3}$, dan di Pusarpedal 91-167 $\mu \mathrm{g} / \mathrm{Nm}^{3}$. Hasil Analisis TSP di Udara Ambien Menggunakan Alat HVAS disajikan pada Grafik 1.

Kadar $\mathrm{PM}_{2.5}, \mathrm{PM}_{2.5-10}$, dan $\mathrm{PM}_{10}$, pada periode pengukuran 25 Agustus sampai 25 September 2008 di beberapa lokasi sampling di Serpong Tangerang di udara ambien menggunakan alat Gent Sampler disajikan pada Grafik 2, dan rerata $\mathrm{PM}_{2.5}$ dan $\mathrm{PM}_{10}$ di setiap lokasi disajikan pada Tabel 1 .

Tabel 1. Nilai Rata-rata $P M_{2,5}$ dan $P M_{10}$

\begin{tabular}{lll}
\hline & \multicolumn{2}{l}{ Nilai rerata $\left(\mu \mathrm{g} / \mathrm{m}^{3}\right)$} \\
Lokasi & $\mathrm{PM}_{2,5}$ & $\mathrm{PM}_{10}$ \\
\hline Setu & 21.01 & 47.73 \\
Pusarpedal & 20.24 & 39.88 \\
Batan Indah & 18.47 & 40.93 \\
BSD & 19.16 & 47.18 \\
\hline
\end{tabular}

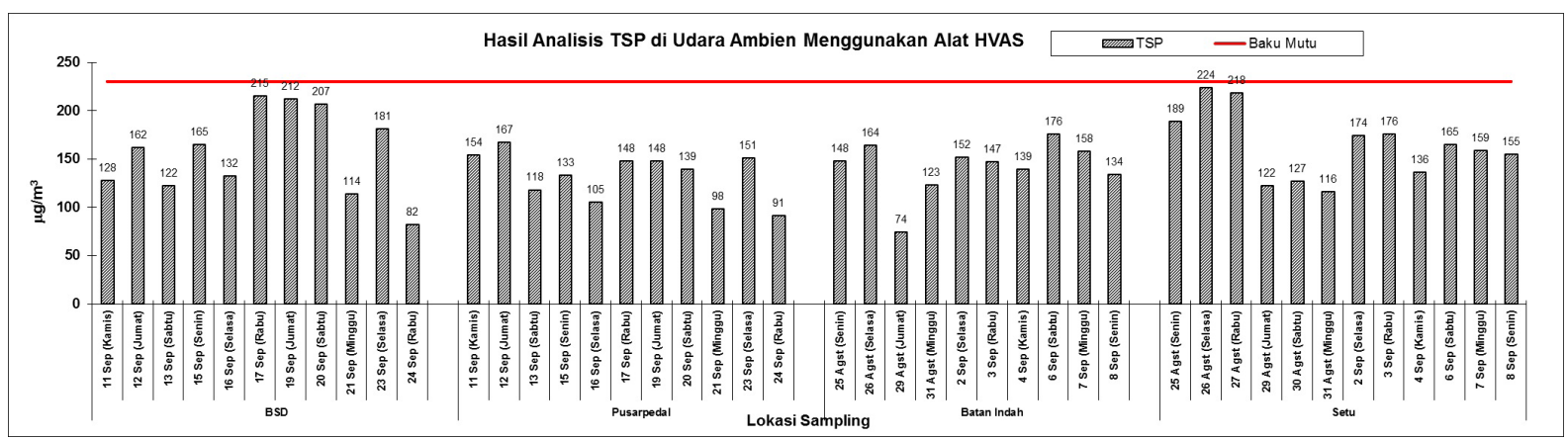

Grafik 1. Hasil Analisis TSP di Udara Ambien Menggunakan Alat HVAS

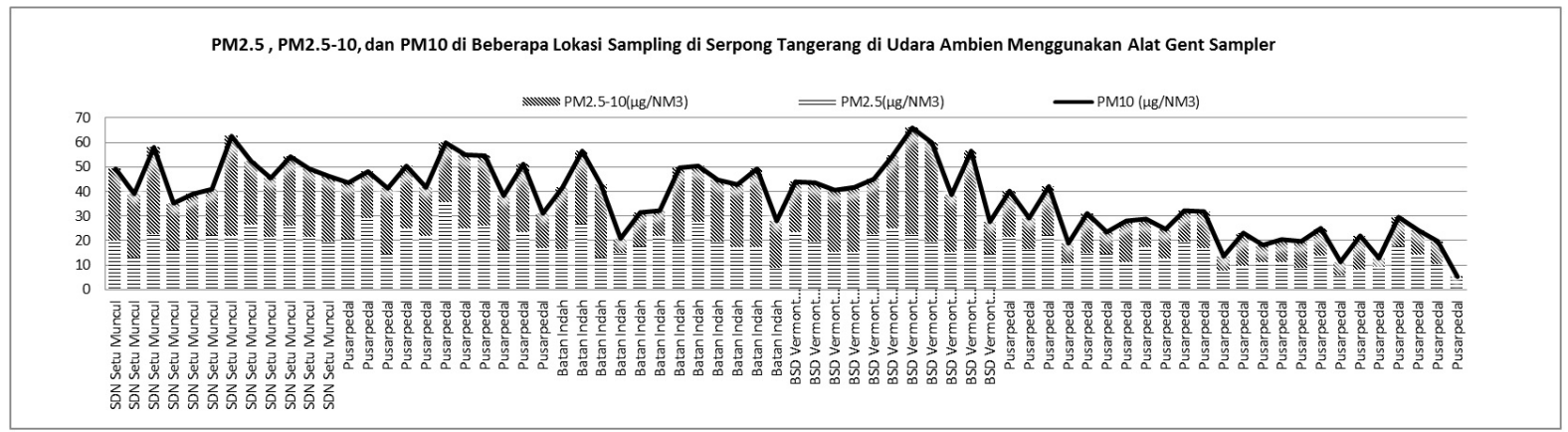

Grafik 2. Kadar $\mathrm{PM}_{2.5}, \mathrm{PM}_{2.5-10}$, dan $\mathrm{PM}_{10}$, Menggunakan Alat Gent Sampler 
Jika dibandingkan hasil pengukuran TSP, $\mathrm{PM}_{2,5}, \mathrm{PM}_{2,5-10}$ menggunakan alat yang berbeda maka diperoleh kecenderungan pola yang sama antara $\mathrm{PM}_{2,5}, \mathrm{PM}_{2,5-10}$ dengan TSP, seperti yang disajikan pada Grafik 3. Grafik batang bagian bawah yang berwarna merupakan konsentrasi $\mathrm{PM}_{2,5}$, grafik batang bagian atas yang tidak berwarna merupakan konsentrasi $\mathrm{PM}_{2.5-10}$ dengan skala yang digunakan pada sisi kiri (skala kecil), dan puncak grafik batang merupakan konsentrasi $\mathrm{PM}_{10}$, untuk TSP ditunjukkan dengan grafik garis dengan penunjuk skala pada bagian kanan (skala besar).

Hasil analisis $\mathrm{Pb}$ di beberapa lokasi telah melebihi baku mutu udara ambien menurut PP41/1999 yaitu $2 \mu \mathrm{g} / \mathrm{m}^{3}$. Kisaran kadar $\mathrm{Pb}$ di Setu 0.21-6.1 $\mu \mathrm{g} / \mathrm{m}^{3}$, Batan Indah 0.4-5.2 $\mu \mathrm{g} /$

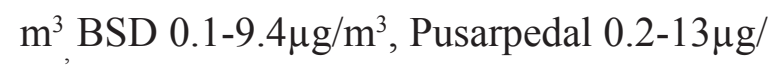
$\mathrm{m}^{3}$. Kadar timbal $(\mathrm{Pb})$ di udara ambien menggunakan alat sampling $H V A S$ dan analisis AAS disajikan pada Grafik 4.

Rerata konsentrasi $\mathrm{Pb}$ pada $\mathrm{PM}_{2,5}$ dan $\mathrm{PM}_{2,5-10}$ untuk lokasi Setu, Pusarpedal, Batan Indah dan BSD disajikan pada Grafik 4 dan Grafik 5, nilai rerata $\mathrm{Pb}$ disajikan pada Tabel 2. Secara umum diperoleh nilai konsentrasi $\mathrm{Pb}$ pada $\mathrm{PM}_{2,5-10}$ lebih besar dibandingkan dengan kadar $\mathrm{Pb}$ yang terdapat di $\mathrm{PM}_{2,5}$. Berdasarkan hasil yang diperoleh tersebut, dapat dinyatakan bahwa kontribusi konsentrasi $\mathrm{Pb}$ terbesar berasal dari partikulat udara yang berdiameter lebih besar.

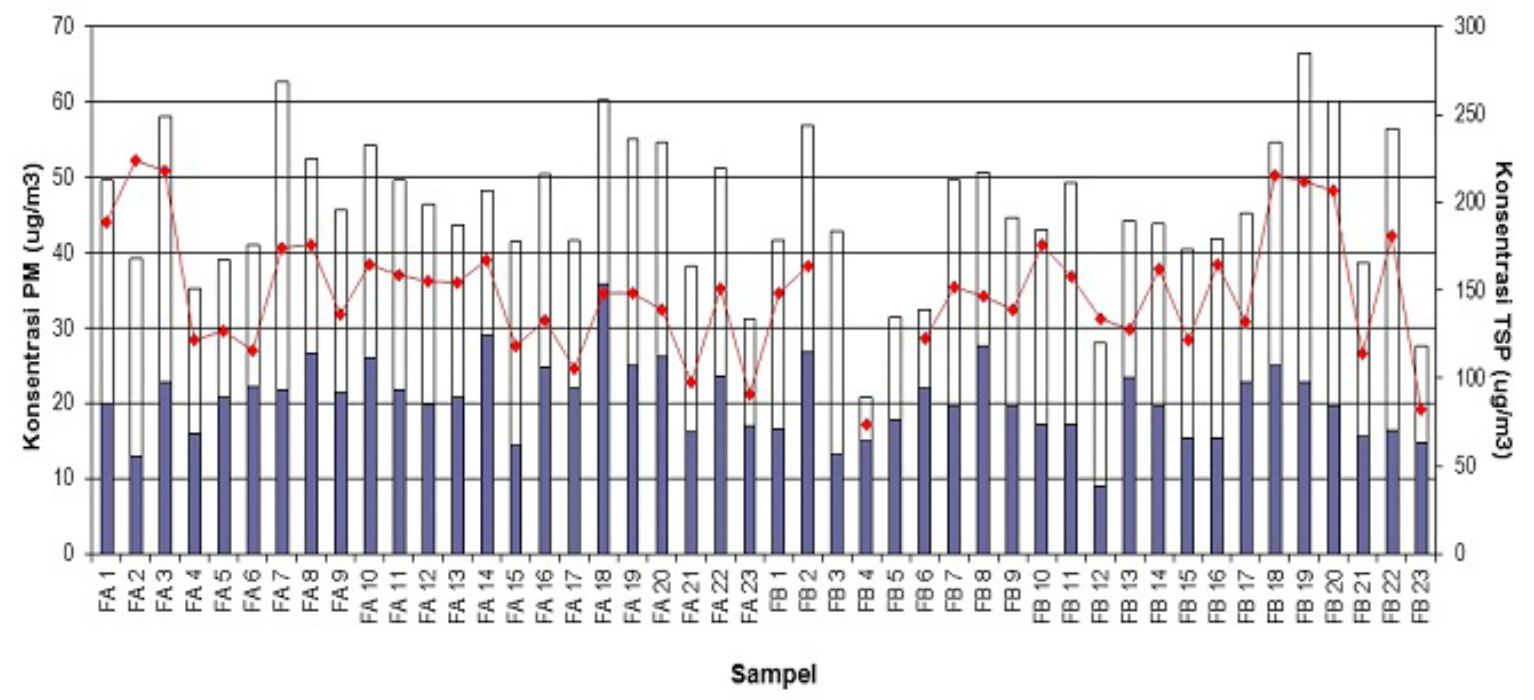

Grafik 3. Perbandingan Kadar TSP, $\mathrm{PM}_{2,5}$, dan $\mathrm{PM}_{2,5-10}$ di Udara Ambien

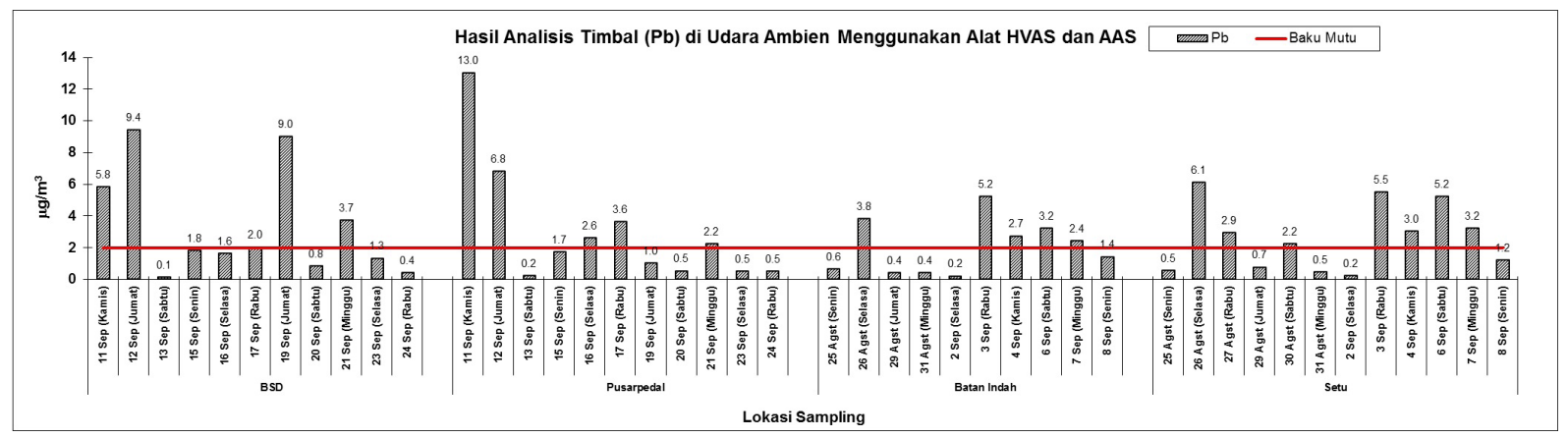

Grafik 4. Kadar Timbal $(\mathrm{Pb})$ di Udara Ambien Menggunakan Alat HVAS 


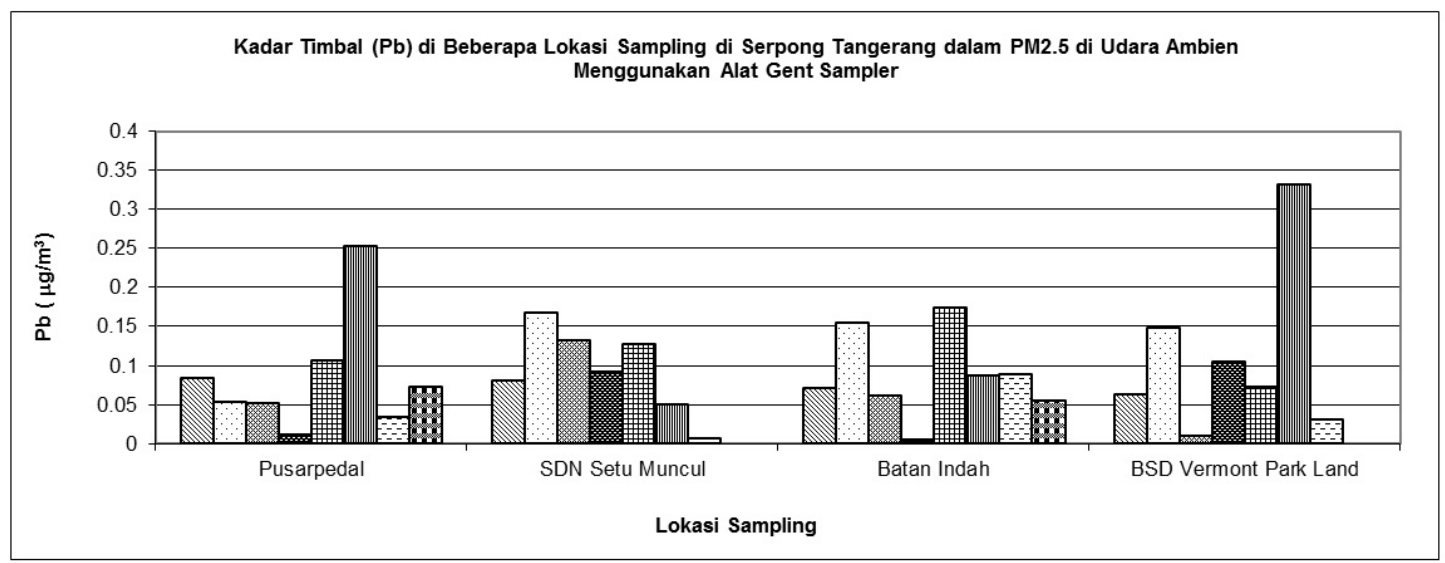

Keterangan: Perbedaan gratik batang menunjukkan perbedaan waktu sampling

Grafik 5. Kadar Timbal $(\mathrm{Pb})$ di Beberapa Lokasi Sampling di Serpong Tangerang Pada $\mathrm{PM}_{2.5}$ di Udara Ambien Menggunakan Alat Gent Sampler

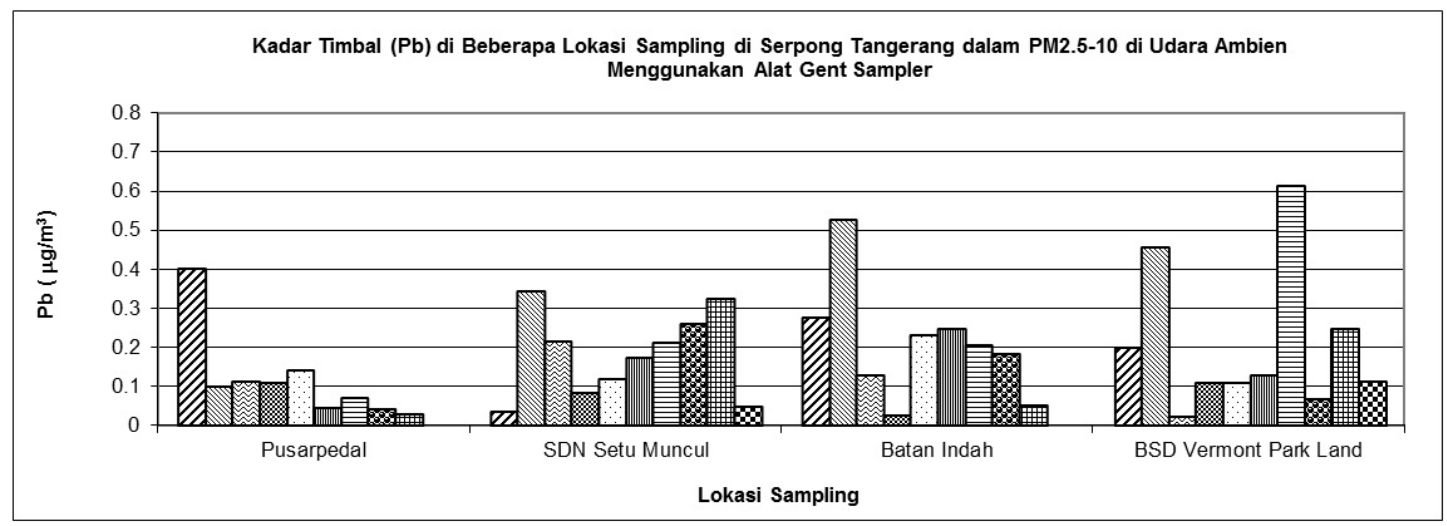

Keterangan: Perbedaan grafik batang menunjukkan perbedaan waktu sampling

Grafik 6. Kadar Timbal (Pb) di Beberapa Lokasi Sampling di Serpong Tangerang Pada $\mathrm{PM}_{2.5-10}$ di Udara Ambien Menggunakan Alat Gent Sampler

Tabel 2. Nilai Rata-rata Timbal (Pb)

\begin{tabular}{lcc}
\hline \multirow{2}{*}{ Lokasi } & \multicolumn{2}{c}{ Nlai rerata $\mathrm{Pb}\left(\mu \mathrm{g} / \mathrm{m}^{3}\right)$} \\
& $\mathrm{PM}_{2,5}$ & $\mathrm{PM}_{2,5-10}$ \\
\hline Setu & 0.13 & 0.18 \\
Pusarpedal & 0.10 & 0.12 \\
Batan Indah & 0.10 & 0.21 \\
BSD & 0.10 & 0.21 \\
\hline
\end{tabular}

Korelasi antara hasil konsentrasi $\mathrm{Pb}$ pada TSP yang disampling menggunakan HVAS dengan $\mathrm{Pb}$ pada $\mathrm{PM}_{2,5-10}$ yang disampling menggunakan Gent sampler di udara ambien di empat lokasi yaitu Setu, Batan Indah, Pusarpedal dan BSD pada waktu yang bersamaan, diperoleh korelasi yang cukup baik dengan nilai korelasi $\mathrm{R}^{2}$ mendekati 0,7 . Adapun korelasi hasil konsentrasi $\mathrm{Pb}$ yang diperoleh dengan menggunakan alat HVAS (dalam TSP) dengan Gent sampler $\left(\mathrm{PM}_{2,5-10}\right)$ disajikan pada Grafik 6. 


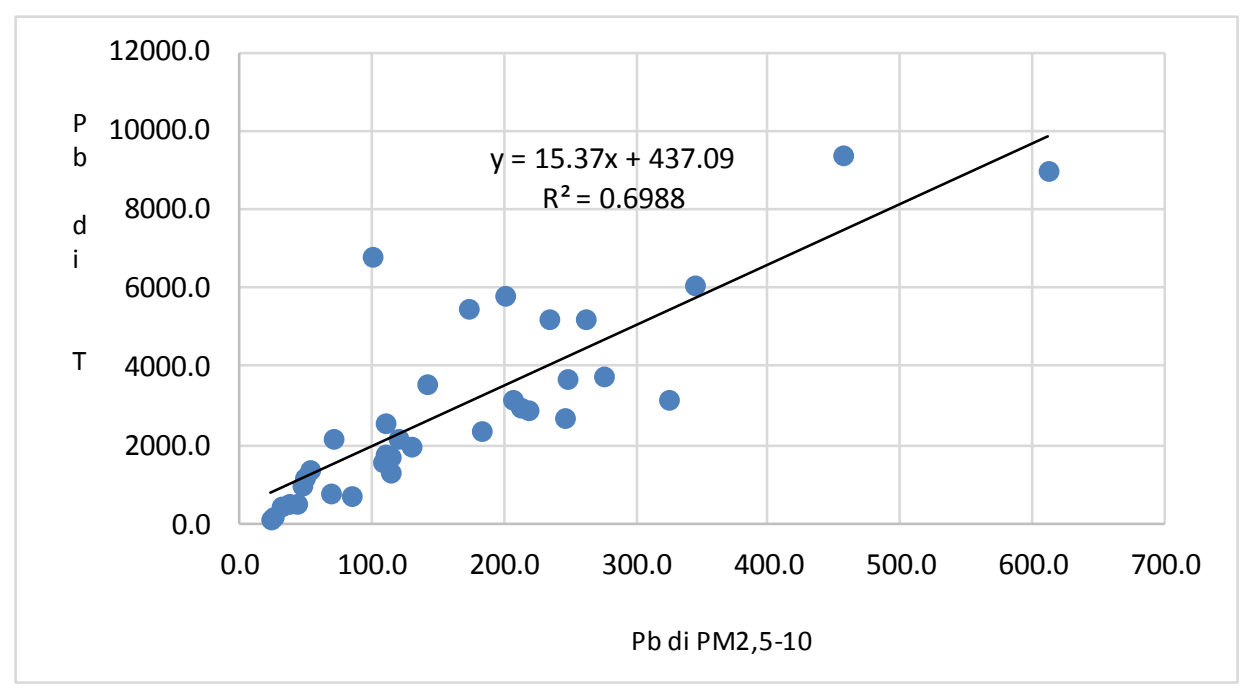

Grafik 6. Korelasi $\mathrm{Pb}$ di $\mathrm{PM}_{2.5}, \mathrm{PM}_{2,5-10}$, dan TSP

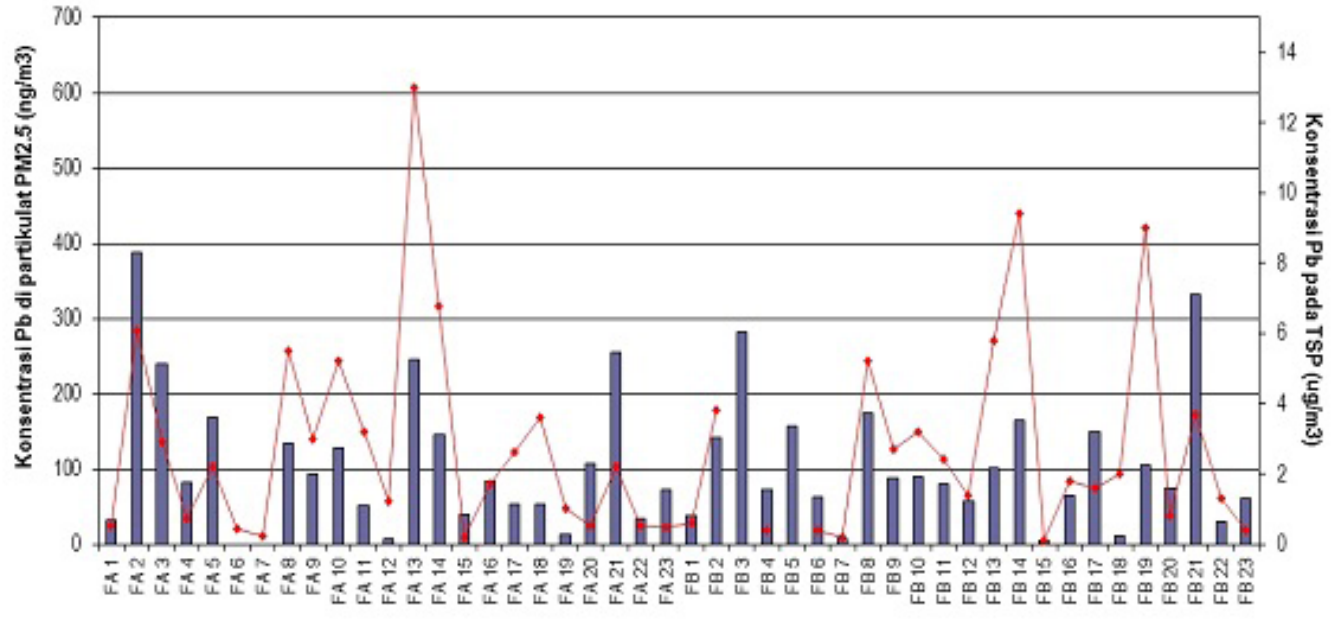

Sampel

Grafik 7. Konsentrasi $\mathrm{Pb}$ di $\mathrm{PM}_{2,5}$ dan TSP

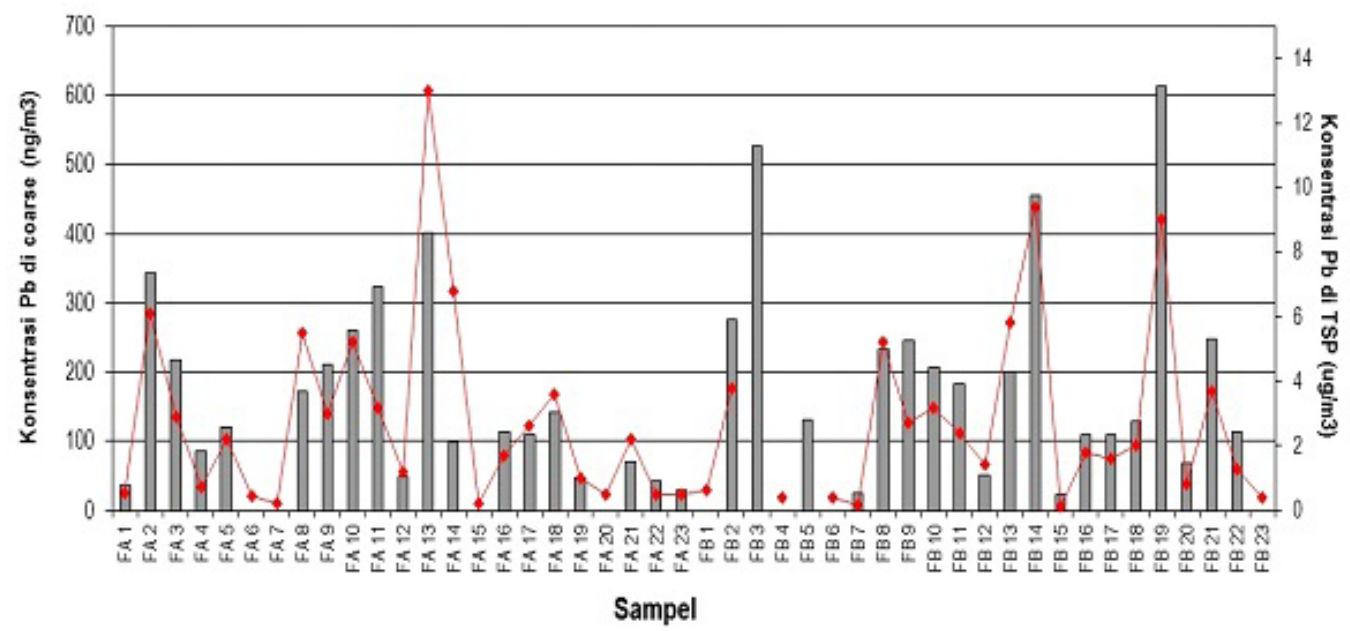

Grafik 8. Konsentrasi $\mathrm{Pb}$ di $\mathrm{PM}_{2.5-10}$ dan TSP 


\section{SIMPULAN}

Hasil pengukuran TSP, $\mathrm{PM}_{2,5}, \mathrm{PM}_{2,5-10}$ menggunakan alat yang berbeda diperoleh kecenderungan pola yang sama. Demikian juga dengan konsentrasi $\mathrm{Pb}$ pada $\mathrm{PM}_{2,5-10}($ Gent sampler) dan konsentrasi Pb di TSP (HVAS) juga mempunyai kecenderungan yang sama. Perbandingan hasil analisis yang diperoleh menunjukkan konsentrasi $\mathrm{Pb}$ pada $\mathrm{PM}_{2,5-10}$ memiliki korelasi yang cukup kuat terhadap konsentrasi $\mathrm{Pb}$ di TSP dengan nilai $\mathrm{R}^{2}$ sekitar 0,7 . Hasil yang diperoleh ini dapat digunakan sebagai data dasar bagi laboratorium yang melakukan pengambilan contoh uji udara ambien. Selain itu, informasi konsentrasi dari salah satu fraksi bisa digunakan untuk memprediksi konsentrasi di fraksi lainnya.

\section{UCAPAN TERIMAKASIH}

Penelitian ini terlaksana atas kerjasama Pusarpedal PSTNT - BATAN Bandung. Penulis juga mengucapkan terimakasih kepada seluruh personil bidang pemantauan serta Bidang Laboratorium Rujukan dan Pengujian khususnya laboratorium udara - Pusarpedal, dan kelompok Teknik Analisis Radiometri Batan yang terlibat dalam sampling dan analisis pada kajian logam berat ini, serta semua pihak yang membantu terlaksananya kegiatan ini.

\section{DAFTAR PUSTAKA}

(1) Peraturan Pemerintah RI No. 41 Tahun 1999 tentang Pengendalian Pencemaran Udara. Kementerian Lingkungan Hidup RI. Jakarta.
(2) Muhayatun, Achmad Hidayat, Diah. Ambien Air Concentration of $\mathrm{PM}_{2,5}$ and $\mathrm{PM}_{10}$ in Bandung and Lembang in 2000-2006. Indonesian Journal of Science and Nuclear Technology 2008; X(1): 53-9

(3) SNI 19-7119.3-2005 tentang cara uji partikel tersuspensi total menggunakan peralatan High Volume Air Sampler (HVAS) dengan metoda gravimetri.

(4) SNI 19-7119.4-2005 tentang Cara uji kadar timbal $(\mathrm{Pb})$ dengan Metoda Dekstruksi Basah menggunakan Spektrofotometer serapan atom

(5) Sampling and Analytical Methodologies for Instrumental Neutron Activation Analysis of Airborne Particulate Matter, Training Course Series No. 4, International Atomic Energy, Vienna (1992).

(6) Atmospheric Environment Vol. 20, No. 5, pp. 845-850, 1986, “The Use Of $\mathrm{Br} / \mathrm{Pb}$ Ratios in Atmospheric Particles to Discriminate Between Vehicular and Industrial lead aerosol sources in the Vicinity of a Lead Works-II., Ellesmere port, Cheshire, W.T. Sturgest and Roy M. Harrison, Department of Environmental Sciences, University og Lancaster, Lancaster LA1 4YQ, England.

(7) Cohen, D, Gras, J, Garton, D, Firestone, T, Johnson , G, Bailey G, Ayers, G, 1997, Study of Fine Atmospheric Particles and Gases in The Jakarta Region. Final Report for Bapedal and East Java Pollution Control Implementation Project. Jakarta. 